\title{
CHANGES OF RUNOFF REGIME ACCORDING TO HUMAN IMPACT ON THE LANDSCAPE
}

\begin{abstract}
Z. Kliment, M. M a to u šk ová: Runoff changes according to human impact on the landscape. - Geografie-Sborník ČGS, 111, 3, pp. 292-304 (2006). - The main aim of our research project was to determine the extent to which the outflow can be influenced by the human interventions in three-selected water basins in Bohemian Forest (Sumava Mountains) and foothills. The rainfall-runoff analyses using both the single and double mass curves over the period of the hydrologic observations were taken as a basic methodology. Beside mean discharge, precipitation, snow and air temperature trends, analysis of land cover change and human impact on the river network and drainage areas development were applied too. The greatest deviations were widely observed in the period between the 2 nd half of the seventies and in the 1st half of the eighties. The whole system came slowly back to its initial condition in the early nineties. The runoff trend deviation has been related to the nature and human factors, mainly to current climatic changes and changes of landscape retention potential.

KEY WORDS: trend analysis - runoff - climate change - human impact - Otava River - Czechia.
\end{abstract}

The presented research was funded by the Research Plan MSM 0021620831 "Geographical Systems and Risk Processes in Context of Global Changes and European Integration" of the Czech Ministry of Education and Research Project VaV-SM/2/57/05 "Long-term changes of river ecosystems in floodplains affected by extreme floods" of the Ministry of Environment of the Czech Republic which is fully appreciated by the authors.

\section{Introduction}

The floods experienced recently in Czechia gave rise to numerous discussions over the changed environment and related potential impacts on the rainfall and runoff processes. Besides climate change, attention is being drawn to human influence. The Czech landscape has developed in a specific way, which differs from region to region in terms of the intensity of anthropogenic intervention into water balance. Not even mountain and foothill areas have escaped such changes.

The impact of human activities on runoff regimes has been proven by a number of experimental studies from various parts of the world, including several from Czechia. An example of this is the long-term research in the experimental water basins concentrated on monitoring the influences of forest and deforestation (Válek 1953; Netopil 1955; Křeček 1980; Kříž 1981, Jařabáč, Chlebek 1984; Šeborová 1994, Blažková 1994). The studies by Kulhavý (1999) and Krečmer (2003) revealed the ambiguity of the results on surface runoff in respect to forest age and species. A higher and less balanced outflow was observed in agriculturally cultivated areas (Föhrer et al. 2001; Klöcking, Haberlandt 2002, Robinson et al. 2003). Another problem is drainage, which affects on average up to $25.5 \%$ of farmland in the Czechia, 


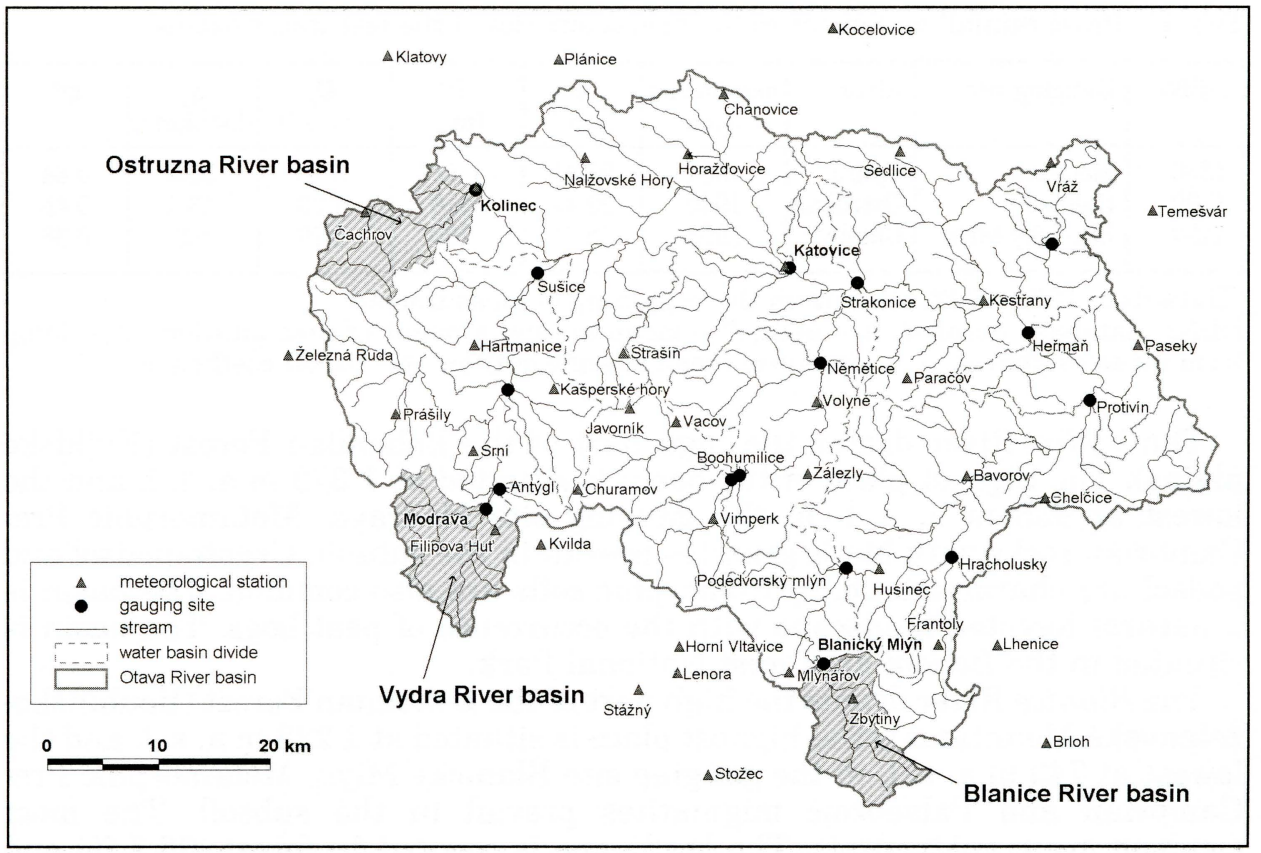

Fig. 1 - Location of the study areas in the Otava River basin: Vydra, Blanice and Ostružná River basins. Source: Basic Water Management Map 1:50 000.

the highest rate in Europe. In general, drainage reduces the level of subsurface water and accelerates and increases the outflow average and minimum (Švihla 1992). The surface drainage contributes to an increase in the discharge effect during the floods (Doležal 2004). Special attention is paid to urban areas often associated with channelization, water reservoirs construction and taking water from rivers (Goudie 1992; Meyer 2001; Sochorec 1977; Lhotský 1999; Kaňok 1999; Kříž 2003).

The main aim of this study is to monitor and try to explain changes in the development of the rainfall - runoff relationship in three water basins situated in the Vltava River headstream area: the Vydra, the Ostružná and the Blanice River basins (see Fig. 1). The selected water basins represent areas of diverse land use with different levels of anthropogenic intervention in the runoff regime. All three basins played an important role during the initial formation of outflow during the catastrophic floods in Czechia in August 2002 (Langhammer et al. 2003; Kliment, Matoušková 2005).

\section{Characteristics of water basins}

The upper stream of the Ostružná River drains the high part of the Bohemian Forest (the Kocháňské plains). Most of the basins belong under the Bohemian Forest foothills. The highest place is situated at $1177 \mathrm{~m} \mathrm{a.} \mathrm{s.} \mathrm{l.,} \mathrm{the} \mathrm{lowest} \mathrm{part}$ at $528 \mathrm{~m}$ a. s. 1 . in the gauging site Kolinec. Metamorphic Pre-Cambrian rocks, orthogneisses and paragneisses, prevail in the subsoil. Cambisols merge into cryptopodsols and podsols at higher altitudes. The landscape is used for agriculture. The forestation reaches $40.7 \%$, arable land accounts for only $17.2 \%$ in the present. The countryside settlement is typical for this area (see Tab. 1). 
Tab. 1 - Basic rainfall and water runoff characteristics of the test water basins

\begin{tabular}{|l|l|l|c|c|c|c|c|c|}
\hline DBNr. & Gauging site & River & $\begin{array}{c}\text { monitoring } \\
\text { from }\end{array}$ & $\begin{array}{c}A \\
\left(\mathrm{~km}^{2}\right)\end{array}$ & $\begin{array}{c}P^{*} \\
(\mathrm{~mm})\end{array}$ & $\begin{array}{c}Q_{a} \\
\left(\mathrm{~m}^{3} \cdot \mathrm{s}^{-1}\right)\end{array}$ & $\begin{array}{c}q_{a} \\
\left(\mathrm{l}^{-1} \cdot \mathrm{km}^{-2}\right)\end{array}$ & $\varphi^{*}$ \\
\hline 1350 & Modrava & Vydra & 1931 & 93.41 & 1327 & 3.18 & 35.2 & 0.84 \\
1390 & Kolinec & Ostružná & 1949 & 92.42 & 916 & 1.20 & 13.1 & 0.45 \\
1450 & Blanický Mlýn & Blanice & 1953 & 85.21 & 760 & 0.79 & 9.2 & 0.38 \\
\hline
\end{tabular}

*Data from 1961-2002, other from the beginning of measurement.

DBNr: database number; $A$ - area, $P$ - mean annual amount of precipitation; $Q_{a}$ - longterm mean discharge, $q_{a}$ - long-term mean specific outflow, $\varphi$ - runoff coefficient

The Vydra River drains the high part of the Bohemian Forest (Kvildské plains). The highest place of the basin is situated at $1373 \mathrm{~m} \mathrm{a} . \mathrm{s} .1$. and the lowest at $935 \mathrm{~m}$ a. s. l. in the gauging site Modrava. Metamorphic PreCambrian rocks with biotic granites prevail in the subsoil. Crypto-podsol and podsol are characteristic, hydromorphic soils are also common. The basin is a natural forested landscape with the occurrence of peat bogs. The basin is situated in the Bohemian Forest National Park.

The Blanice River drains the high part of the Bohemian Forest (Boubínskoželnavské Mountains). The highest place is situated at $1228 \mathrm{~m}$ a. $\mathrm{s}$. l. and the lowest at $743 \mathrm{~m}$ a. s. l. in the gauging site Blanický Mlýn. Metamorphic PreCambrian and Palaeozoic migmatites prevail in the subsoil. The most common are cryptopodsols. The landscape is covered by forest $(66.7 \%)$ and meadows $(27.7 \%)$. At present, a cattle breeding is typical for the area.

\section{Methods and data sources}

The methodology of the research comprises analytical and synthetic procedures. The basic analytical procedure can be regarded as the analysis rainfall and runoff trend regime supplemented by an analysis of air temperature and snow parameters relationships. The method of simple and double mass curves was used as the main method for the evaluation of the trend in outflow values development in the selected water basins. Significant deviations from the linear course together with sudden variations can indicate changes in the runoff regime. Besides simple mass curves for basic discharge characteristics and precipitation, double mass curves for cumulative precipitation and discharge values were plotted for a better identification of changes in the trend. The analysis itself was preceded by the necessary step of homogenizing the precipitation data, during which missing data was completed on the results of a regressive analysis of the time sequences of monthly precipitation from adjacent stations. Thiesen polygons method was used first to derive the precipitation in the water basins. Subsequently, a method taking into account the altitude was used (Kavan 2004).

During the next step, a frequency analysis of high water level events was carried out. The frequency was assessed based on the occurrence of five-year and larger events respecting the separation of individual flood waves. The analysis of runoff changes trend was followed through by an analysis of changes in the runoff distribution during the year.

The development of runoff in the given water basins was further supplemented by an analysis of the development of air temperature and snow characteristics (number of days with snow cover; average and maximum snow 
cover depth). Trends were described in the form of 5-year moving averages of monthly, annual and seasonal values. The basic source of input outflow and climate values was the Czech Hydrometeorological Institute (CHMI) database.

Following the analysis of the trends in runoff, rainfall and air temperature regimes, analysis of changes in landscape use, river network training and land drainage were carried out. The results were related to the duration of the water level monitoring in the given water basins, i.e. over approximately the last 50 years. Changes in land use were assessed based on cadastre register (Bičík et al. 2003) and with the help of database CORINE Land cover (1992, 2000). The human impact on the river network was evaluated based on Water Management Maps (WMM) 1:50 000 and on materials provided by the Agricultural Water Management Authority (AWMA). Land drainage and its development over time was derived from map documents with a scale of 1:10 000, as provided by AWMA. The existing analogue and digital databases, as well as the terrain research itself, were used.

\subsection{Analysis of rainfall-runoff regime trends}

The method of simple and double mass curves was used for the identification of significant changes in the water runoff regime. Considerable changes were identified in the Ostružná River basin, where an increase in runoff was recorded in the period 1975-1980. A less considerable change in the trend in the period 1975-1982 was also confirmed on the Blanice River. On the contrary, on the Vydra River no changes in the water runoff regime were identified (see Fig. 2).

An analysis of the high water level occurrence was carried out in order to explain the cause of significant changes in the runoff trend. The 5-year event level was used as the limit for high discharges. It was derived empirically using

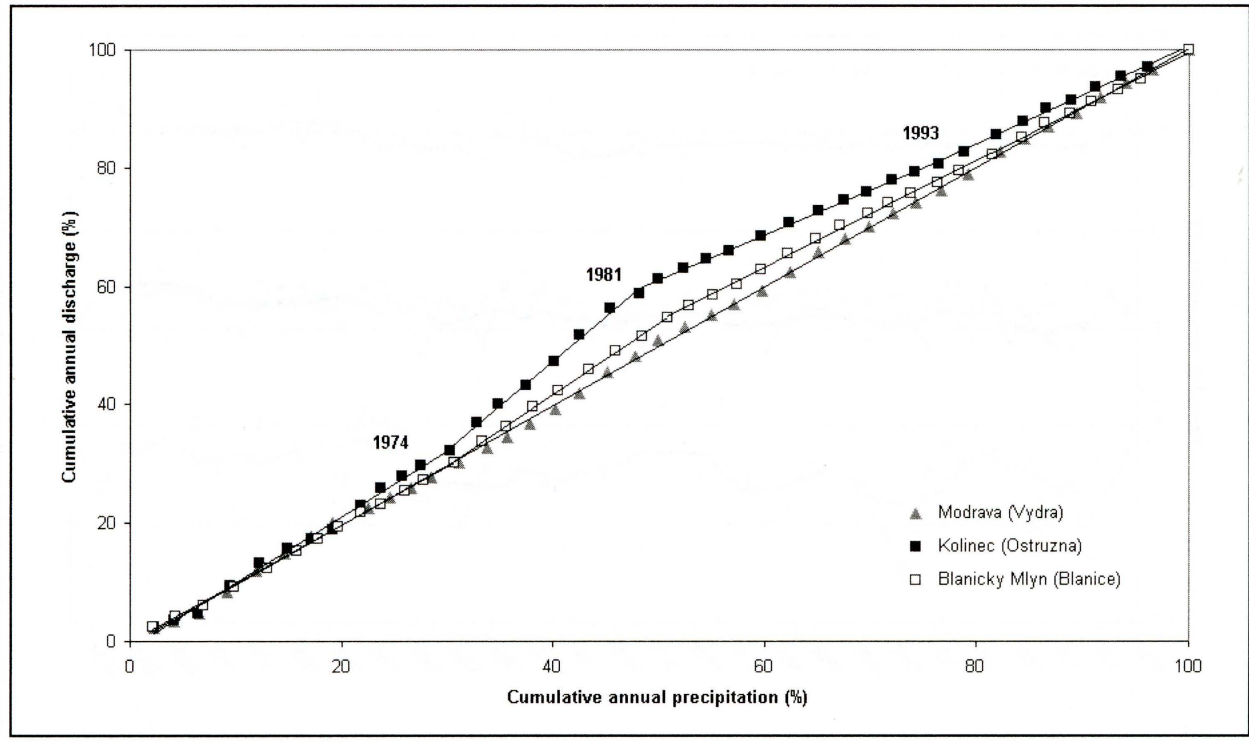

Fig. 2 - Double mass curves of annual precipitation and discharge for gauging sites: Modrava, Kolinec, Blanický Mlýn. Source: CHMI. 
probability curves. The analysis confirmed that the identified trend in the water runoff increase is connected with the occurrence of a high water level. In the period 1979-1981, a concentrated occurrence higher water level events recorded all the observed gauging sites. The occurrence of a high water level was on the Vydra River did not manifest itself significantly changes in the longterm runoff regime. Based on these facts the occurrence of flood discharge is not a determining factor in changes in the water runoff development.

Seasonal runoff changes within a year were assessed based on the development of the percentage share of runoff both in individual months and individual seasons. What is characteristic for the water runoff regime in the last 50 years is the considerable increase (of more than $5 \%$ ) in the winter months, particularly after 1975 . On the other hand, we can see a gradual decrease in the runoff in summer months for the same period, with exception floods in August 2002. The largest increase is in December and the largest decrease is in July. Monthly and seasonal shares of precipitation remain approximately the same in the given seasons without perceptible trends or deviations. The Vydra River basin does not display any significant changes in its water runoff distribution.

Tab. 2 - Mean annual air temperature and snow cover characteristic

\begin{tabular}{|l|c|c|c|}
\hline Climatic stations & Klatovy & $\begin{array}{c}\text { Kašperské } \\
\text { Hory }\end{array}$ & Churáňov \\
\hline Altitude (m a.s.l.) & 430 & 737 & 1118 \\
Mean air temperature $\left({ }^{\circ} \mathrm{C}\right)$ & 8.1 & 6.2 & 4.4 \\
Mean precipitation $(\mathrm{mm})$ & 607 & 830 & 1098 \\
Mean snow cover depth $(\mathrm{cm})$ & 6.6 & 14.3 & 39.1 \\
Mean maximum snow cover depth $(\mathrm{cm})$ & 17,5 & 39.3 & 97.5 \\
Mean numbers of day with snow cover & 49.9 & 88 & 143.9 \\
\hline
\end{tabular}

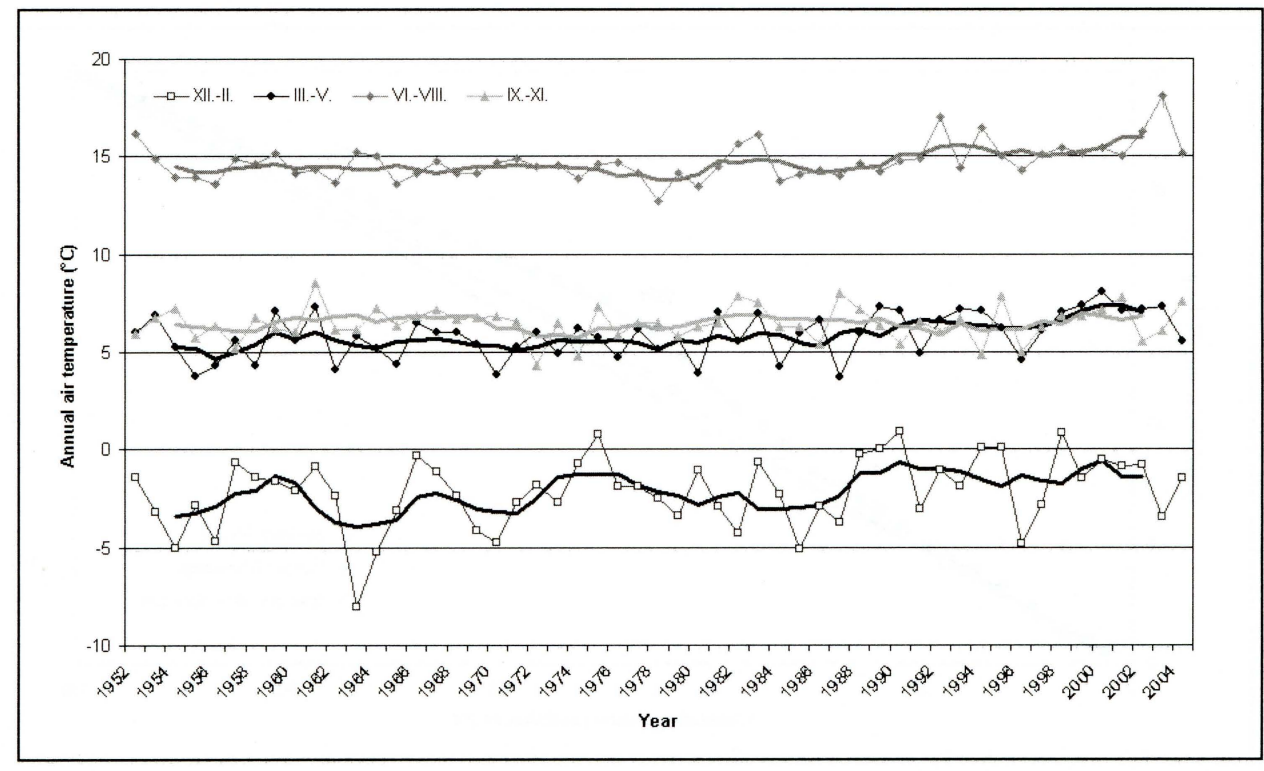

Fig. 3 - Development of mean air temperature in season periods. 5-years moving averages were used. Climatic station Kašperské Hory. Source: CHMI. 
Changes associated with global warming have been frequently discussed in the last few decades. Snow and air temperature parameters were compiled from three climate stations. The stations are at different altitudes in the Bohemian Forest and foothills: Churáňov, Kašperské hory and Klatovy (see Tab. 2). The Klatovy station has the longest monitoring sequence, allowing air temperature characteristics to be related to the beginning of the last century. By comparing average values for the periods 1901-1950 (Vesecký et al. 1961) and $1951-2003$, a rise in temperature from $7.6{ }^{\circ} \mathrm{C}$ to $8.1{ }^{\circ} \mathrm{C}$ was identified. The last 50-year monitoring period shows a significant rise in air temperature in the 1980s and, in particular, from the beginning of the 1990s. Certain signs, particularly during the winter season, can already be observed in the 1970s. The biggest rises in air temperature are observed in February and August and also in January, May and March. The situation is depicted in Figure 3. Similar trends were observed for all three stations.

The average number of days with snow covers for the period $1950 / 51-2003 / 04$ is practically the same as the average value for the period 1920/21-1949/50 (about 50). A certain reduction in the number of days of snow cover can be seen from the 1970s and, more significantly, during the $1990 \mathrm{~s}$. At the same time, despite the apparent increase in winter precipitation, the average snow cover depth was reduced by almost a half for comparable amounts of winter precipitation.

The period of the identified increase in water runoff (1975-1982) can be characterized as average from a temperature perspective, with a higher average snow cover depth and a higher number of days with snow cover. The significant increase in spring and summer temperatures from the beginning of the $1980 \mathrm{~s}$ could then contribute to the reduction in water runoff, particularly in the summer months.

\subsection{Land Cover Changes Analysis}

The long-term trends of the changes in the mountain and foothill landscape in the Bohemian Forest can be monitored based on statistical data from cadastre

Tab. 3 - Land cover changes for study water basins (source: CORINE Land cover)

\begin{tabular}{|ll|r|r|r|r|r|r|}
\hline \multirow{2}{*}{ Units } & CORINE land cover & \multicolumn{2}{|c|}{$\begin{array}{c}\text { Ostružná } \\
\text { (Kolinec) }\end{array}$} & \multicolumn{2}{c|}{$\begin{array}{c}\text { Blanice } \\
\text { (Blanický Mlýn) }\end{array}$} & \multicolumn{2}{|c|}{$\begin{array}{c}\text { Vydra } \\
\text { (Modrava) }\end{array}$} \\
\cline { 3 - 7 } & & $\begin{array}{r}1992 \\
\text { (\%) }\end{array}$ & $\begin{array}{c}2000 \\
(\%)\end{array}$ & $\begin{array}{c}1992 \\
(\%)\end{array}$ & $\begin{array}{c}2000 \\
(\%)\end{array}$ & $\begin{array}{c}1992 \\
(\%)\end{array}$ & $\begin{array}{c}2000 \\
(\%)\end{array}$ \\
\hline 112 & Discontinuous urban fabric & 0.9 & 1.3 & 0.3 & 0.3 & 0.0 & 0.0 \\
211 & Non-irrigated arable land & 45.7 & 17.2 & 5.7 & 0.3 & 0.0 & 0.0 \\
222 & Fruit trees and berry plantations & 0.3 & 0.0 & 0.0 & 0.0 & 0.0 & 0.0 \\
231 & Pastures & 4.7 & 30.2 & 22.3 & 16.9 & 4.2 & 5.7 \\
243 & Land principally occupied by & & & & & & \\
& agriculture with significant areas & & & & & & \\
& of natural vegetation & 11.1 & 10.1 & 6.7 & 3.9 & 0.0 & 0.0 \\
311 & Broad-leaved forest & 0.0 & 0.5 & 0.2 & 0.8 & 0.0 & 0.0 \\
312 & Coniferous forest & 32.5 & 37.9 & 41.9 & 61.2 & 65.2 & 58.1 \\
313 & Mixed forest & 1.7 & 1.2 & 7.2 & 2.3 & 0.3 & 1.0 \\
321 & Natural grassland & 0.0 & 0.0 & 3.0 & 10.8 & 1.1 & 1.1 \\
324 & Transitional woodland shrub & 3.0 & 1.7 & 12.6 & 3.4 & 29.2 & 34.2 \\
& Total area of the river basins & 100.0 & 100.0 & 100.0 & 100.0 & 100.0 & 100.0 \\
\hline
\end{tabular}


unit records. The landscape changes reflect changes in political and economic conditions. According to Bičík et al. (2003), which compared the structure of land use in the periods 1845-1948-1990, there was a significant decrease of arable land at higher altitudes (above $800 \mathrm{~m}$ above sea level) after 1948. The decrease in arable soil was compensated by the growth of forest. The amount of arable land at lower altitudes remained approximately constant. However, the structure of the landscape changed significantly during the period of socialistic agriculture mainly during 1960 s-1980s. Introduction of large-area farming led to the loss of the stabilizing elements in the landscape. Intensive agriculture was accompanied on the extensive land drainage of swamped areas and the straightening of smaller rivers. Such changes could negatively affect the outflow characteristics. As a result of state subsidies, the Bohemian Forest foothill areas have been extensively grassed over after 1994 (see Tab. 3).

The river basins monitored are different in terms of the land use and their development over the last 50 years. The Ostružná river basin, where arable land used to cover over $45 \%$ of the area in the past, has experienced the biggest changes. In the 1990s most of the previously farmed land has been grassed over (see Fig. 4). Similar changes together with the forestation have also occurred in the Blanice River basin. Such changes could contribute to the increase in the landscape retention and to the reduction in average and minimum values of surface runoff.

3.4 River network training and land drainage analysis

River training and amelioration measures represent other significant anthropogenic intervention in the river basins. The first initial modifications

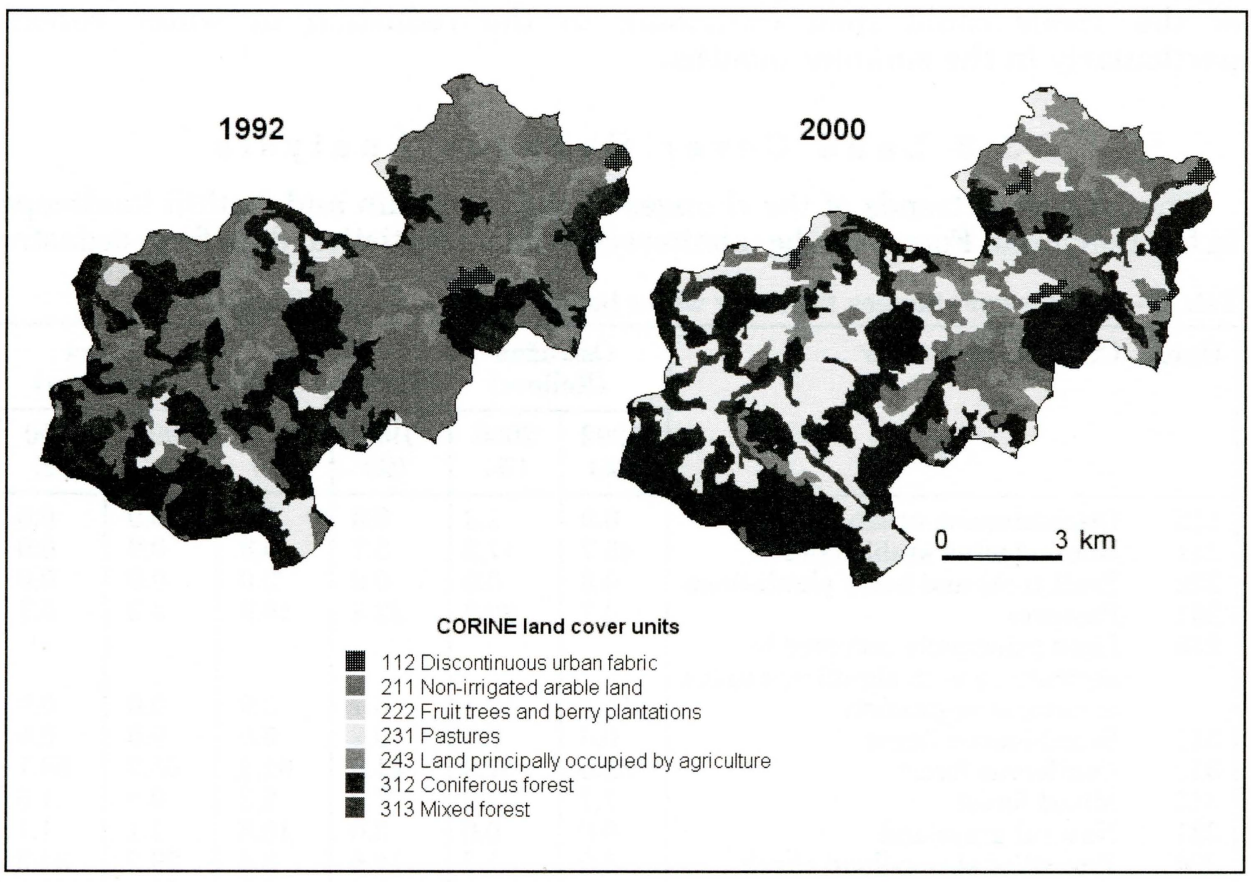

Fig. 4 - Land cover changes in the Ostružná River basin. Source: CORINE Land cover. 
Tab. 4 - River altering in the Ostružná and Blanice River basins

\begin{tabular}{|l|c|c|}
\hline & Ostružná & Blanice \\
\hline River network length $(\mathrm{km})$ & 163.9 & 141.9 \\
River altering length $(\mathrm{km})$ & 33.7 & $8,5\left(18.4^{*}\right)$ \\
Transformation degree $(\%)$ & 20.6 & $6\left(13.0^{*}\right)$ \\
\hline
\end{tabular}

*Including historical alterations, which are now of an almost natural character of river network in 19th century did not represent significant interventions into the river habitat, i.e. river network lengths did not experience any significant changes. Natural materials were mainly used for the alterations. More significant impact into the river network has occurred in

connection with flood protection, urbanization and amelioration measures. The main river alterations were carried out between 1960 and 1987 in connection with the drainage of farmland in the Ostružná and Blanice River basins. The highest level of channelization is displayed in the Ostružná river basin, where the tributaries of the main river are chiefly affected (21\%). The river channels were straightened, deepened and stabilized using concrete prefabricated elements (see Tab. 4).

The Blanice River basin has a significantly lower level of channelized sections mainly in the Zbytinský Brook basin. The level of river altering totals only $6 \%$ in the whole Blanice River basin but in the Zbytinský Brook basin reaches $62 \%$ (Vondra 2004). No significant anthropogenic interventions to the river network were identified in the Vydra River basin except of forest amelioration in the 19th and 20th centuries (Hais 2004).

The land drainage was carried out in connection with intensive agriculture in particular. The first interventions were carried out during the $1960 \mathrm{~s}$. The

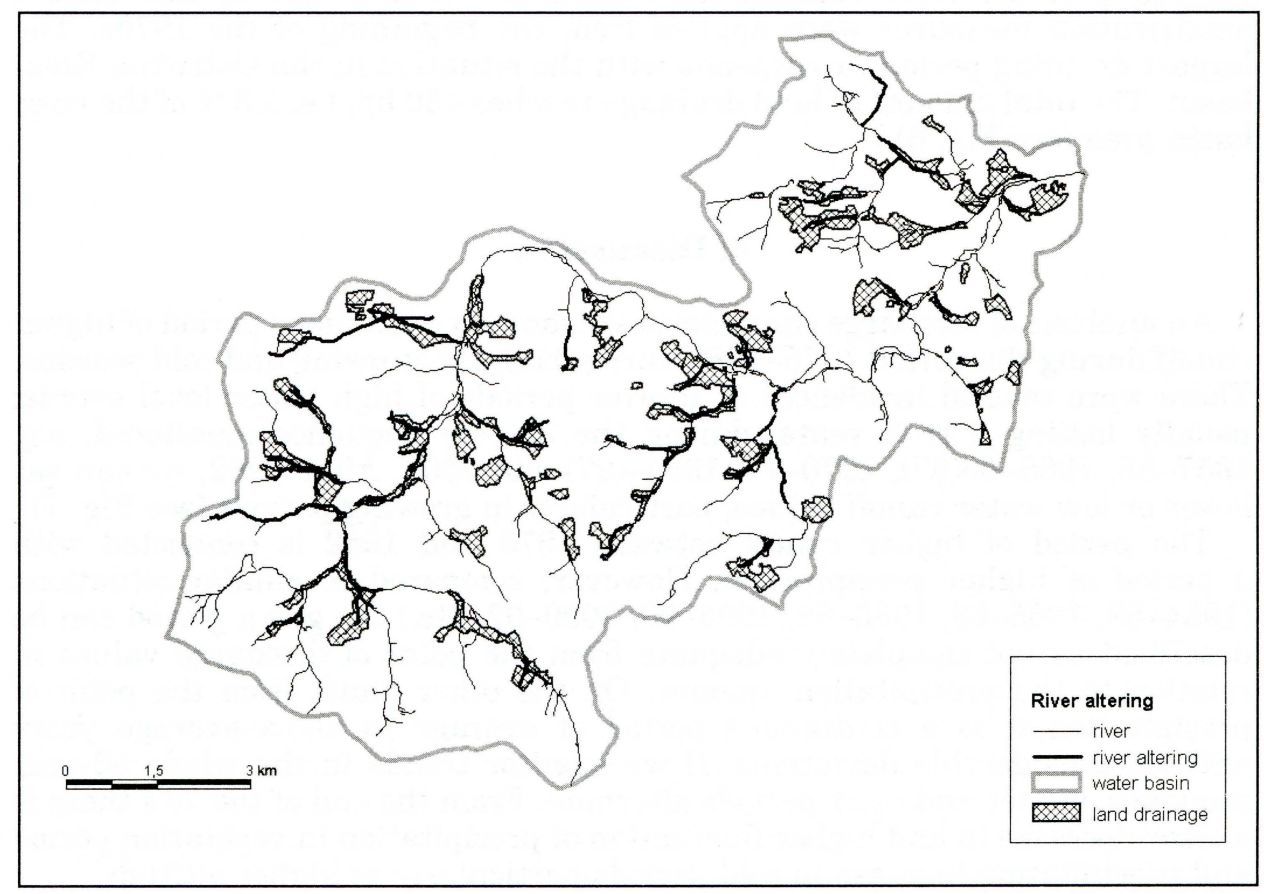

Fig. 5 - River training and land drainage in the Ostružná River basin. Source: AWMA Prachatice. 


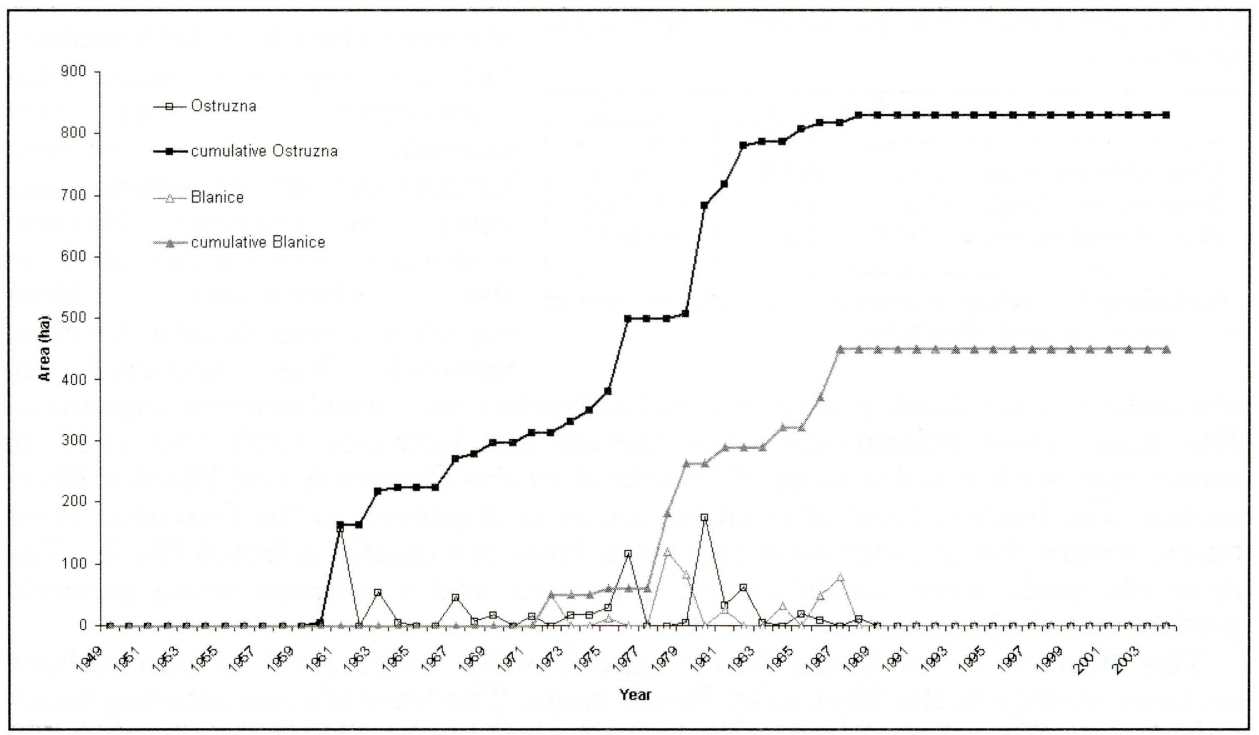

Fig. 6 - Land drainage in the Ostružná and Blanice River basins. Source: AWMA Prachatice.

largest growth in the size of drained areas occurred between 1975 and 1982. The total amount of the drainage reaches 829 ha in the Ostružná river basin, i.e. $8.3 \%$ of the river basin area (see Fig. 5). In the case of the Blanice amelioration measures were applied from the beginning of the 1970s. The largest draining period corresponds with the situation in the Ostružná River basin. The total amount of land drainage reaches 450 ha, i.e. $5.3 \%$ of the river basin area (see Fig. 6).

\section{Discussion}

An analysis of discharge characteristics shows a continuous period of higher runoff during the period 1975-1982 during both the growing and cold seasons. There were several incidences of shorter periods of high water level events; usually lasting 2 to 3 years, during the 50-year sequence monitored, e.g. 1957-58, 1965-66(67), 1970-71, 1995-(97) and 2002. After 1982, we can see lower or low water runoff values, particularly in growing periods (see Fig. 7).

The period of higher runoff between 1975 and 1982 is connected with a period of higher precipitation. However, compared to similar situations (1954-58, 1965-68, 1986-88, 1995-96, 2000-02, etc.) the given period can be described as not completely adequate from the point of discharge values in relation to the precipitation amount. On the other hand, from the point of precipitation it is a continuous period of average to above-average years without considerable deviations. If we monitor trends in the whole 50-year sequence, wetter and drier periods alternate. From the end of the 70's there is a clear decrease in and higher fluctuation of precipitation in vegetation period and precipitation increase in cold periods particularly at higher altitude.

In terms of air temperature, the period 1975-1982 is one of below-average and very cold periods. Low average temperature values were mainly observed 


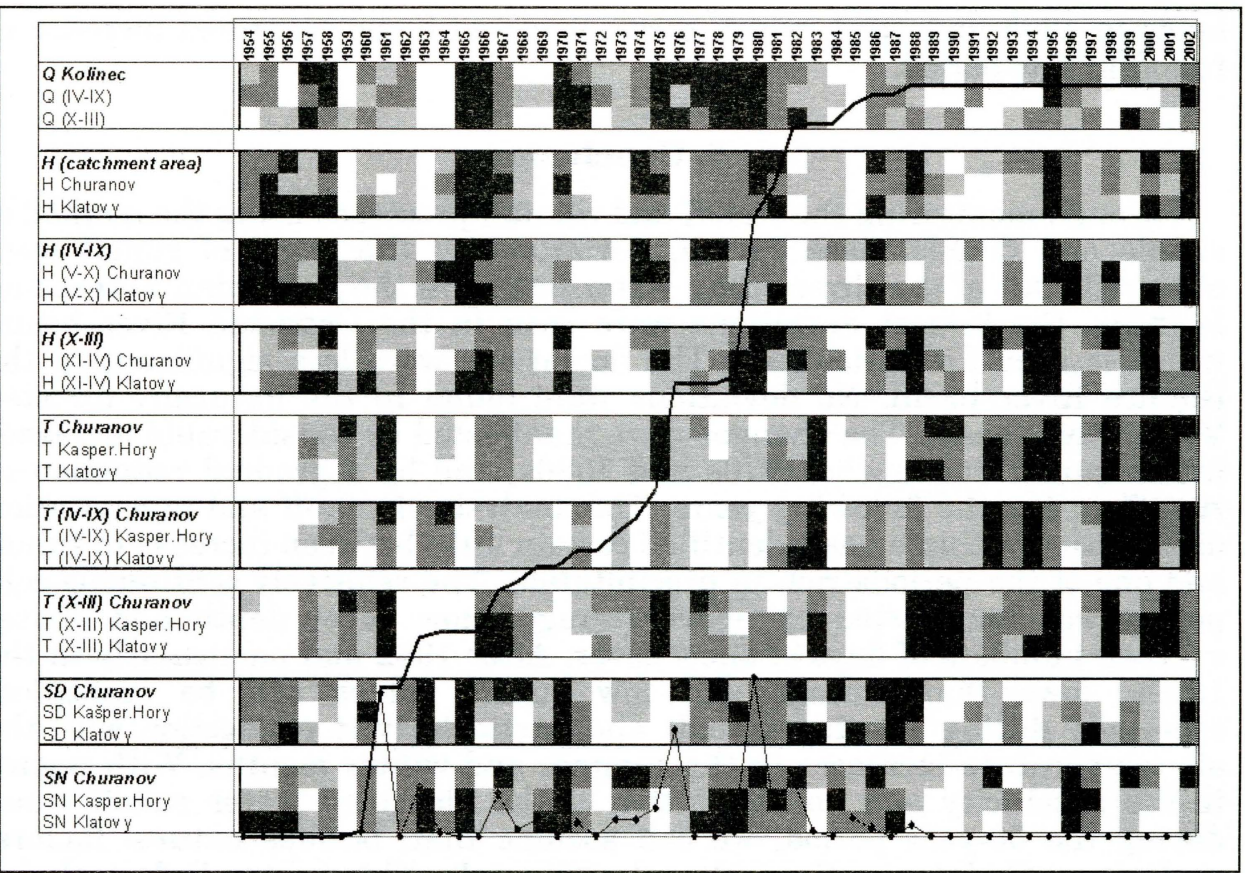

Fig. 7 - Climate development and increase of land drainage in the Ostružná River basin in period 1954-2002. Source: CHMI, AWMA. $Q$ - mean discharge, $H$-precipitation, $T$ - mean air temperature, $S D$ - snow cover depth, $S N$ - number of days with snow cover. Black colour areas: values > upper quartil, grey dark: < upper quartil, median>, grey light: $<$ median, lower quartil >, white: <lower quartil. Thin line - development of land drainage, thick line - development of land drainage (cumulative).

in the growing periods. Conversely, slightly above-average temperatures were reached in winter period. Looking at the 50-year sequence as a whole, there is air temperatures increase considerably from the beginning of the $1980 \mathrm{~s}$ and more so during the $1990 \mathrm{~s}$, during both summer and winter months.

Above-average depths of snow cover characterize the period 1975-1982. The number of days of snow cover is also above average. In connection with increased temperatures, reduced snow cover depths and the number of days with snow cover can be observed from the end of the 1980s. One of the consequences of these factors is the change in the water runoff distribution during the year in favour of the winter months (from the mid-1970s).

In the period 1845-1990 no significant land cover changes were identified in study water basins. Nevertheless, there were significant changes in the structure of the landscape as a result of the introduction of large-area farming. A significant reduction of arable land (particularly in the Ostružná River basin) was in the 1990s, which was compensated for by an increase in meadows and forests areas. These changes can be seen as positive in terms of the higher landscape water retention and the evapotranspiration process.

Extensive amelioration measures were carried out in the Ostružná and Blanice River basins in the second half of the 20th century. Large areas used for agriculture were drained and, in connection with this, small river channels were altered. The greatest increase in drained areas occurred 
between 1975 and 1982, which corresponds with the identified increase in runoff in this period.

\section{Conclusion}

Through monitoring the runoff and rainfall processes using the method of simple and double mass curves, deviations in the trend of runoff were observed. Out of the three study water basins in the Bohemian Forest and foothills, the largest deviations were seen in the Ostružná River basin, which is used for agriculture. The deviations were less significant in the Blanice River basin. No deviations were found in the naturally forested Vydra River basin. The changes were manifested by considerable increases in the runoff during the $1970 \mathrm{~s}$ and $1980 \mathrm{~s}$, and by a gradual reduction in runoff during the following years. The analysis of runoff and precipitation distribution within a year identified certain links between increase in runoff and one of the periods rich in precipitation. The relatively continuous cold period was manifested by above-average snow cover depth and aboveaverage numbers of days of snow cover. After 1982 and particularly in the $1990 \mathrm{~s}$, lower-than-average and low runoff values can be identified; especially during growing periods and particularly in connection with the air temperature increases in the summer and winter months. With regard to the specificity and non-repetition of the identified water runoff trend during the 50-year period, we can assume that, besides natural factors, anthropogenic interventions also played a role. This particularly includes the extensive amelioration measures, river network training and the construction of drainage systems. The period with the most intensive increase in drained areas corresponds with the increase in water runoff. Conversely, the significant reduction in arable land areas in the last ten years, together with the identified climatic trends, could contribute to the increase in the evapontranspiration. It could cause the overall reduction in runoff. Determining the importance and influence of the factors affecting the water runoff seems to be very difficult.

\section{References:}

BLAŽKOVÁ, S., KOLÁÁROVÁ, S. (1994): Vliv odlesnění na hydrologický režim v oblasti Jizerských hor. VÚV T.G.Masaryka., Praha, 76 p.

BIČ́́K, I. et al. (2003): Vývoj struktury ploch v povodí Otavy. In: Langhammer, J. (ed.): Hodnocení vlivu změn přírodního prostředí na vznik a vývoj povodní. Sborník výstupù $\mathrm{z}$ dílčích úkolů grantu GAČR. PřF UK, Praha, pp. 113-121.

DOLEŽAL, F. et al. (2004): Bilanční odhady př́spěvku odvodňovacích soustav $\mathrm{k}$ průběhu povodní. VÚMOP, Praha.

FÖHRER, N. et al. (2001): Hydrological response to land use changes on the catchment scale. Physics and Chemistry of the Earth, 26, pp. 577-582.

GOUDIE, A. (1992): The human impact on the natural environment. Blackwell Publisher, Oxford.

HAIS, M. (2004): Influence of drainage on landscape functioning in Šumava National Park. In.: Hermann A. (ed.) Extended Abstract - International conference on Hydrology of Mountains Environments. Berchtesgaden, $125 \mathrm{p}$.

JARABÁČ, M., CHLEBEK, A. (1984): Vliv lesủ a lesního hospodářství na odtoky vod a erozi půdy v Beskydech. Vodní hospodářství, No. 4, Praha, pp. 109-116.

KAN̂OK, J. (1999): Antropogenní ovlivnění velikosti prùtokủ řek povodí Odry po profil Kozle. Spisy prací Př́rodovědecké fakulty Ostravské univerzity, No. 10, Ostravská univerzita, Ostrava. 
KAVAN, J. (2004): Změna odtokových poměrů v povodí Ostružné. Bakalářská práce, PřF UK Praha, $75 \mathrm{p}$.

KLIMENT, Z., MATOUŠKOVÁ, M. (2005): Trendy ve vývoji odtoku v povodí Otavy. Geografie-Sborník ČGS, 112, No. 1, pp. 32-45.

KLÖCKING, B., HABERLANDT, U.(2002): Impact of landuse changes on water dynamics - a case study in temperate meso and macroscale river basin. Physics and Chemistry of the Earth, 27, pp. 619-629.

KŘEČ́EK, J.(1980): Prognóza vlivu lesní těžby na změnu vodnosti malého povodí. Práce VÚLHM, 56, Praha.

KŘÍŽ, V. (1981): Nástin prognózy potenciálních změn hydrického režimu Moravskoslezských Beskyd. Sborník ČSG, 86, No. 1, Academia, Praha, pp. 19-27.

KŘİŽ, V. (2003): Změny a zvláštnosti vodního režimu řeky Ostravice. Geografie, 108, No. 1, pp. 36-48.

KULHAVÝ, Z. (1999): Hodnocení vlivu zemědělského hospodaření na odtokové poměry malých povodí aplikací metod matematického modelování. ZZ EP 7062, VÚMOP, Praha.

LANGHAMMER, J. et al. (2003): Hodnocení vlivu změn př́rodního prostředí na vznik a vývoj povodní. Sborník výstupů z dílčích úkolů grantu GAČR, PřF UK, Praha, 200 p.

MEYER, W.B. (2001): Human impact on the Earth. Cambridge University Press, Cambridge.

NETOPIL, R. (1955): Výzkum vlivu lesa na odtok. Sborník ČSZ, 60, No. 1, Academia, Praha, pp. 65-66.

ROBINSON, M. et al. (2003): Studies of the impact of forest on peak flows and baseflows: a European perspective. Forest ecology and management, 186, pp. 85-97.

SOCHOREC, R. (1997): Ovlivnění hydrologických charakteristik odběry povrchové vody a vypouštěním vody do toků v povodí Odry a horního toku Moravy. Vodní hospodářství, 47, No. 9., pp. 291-292.

ŠEBOROVÁ, V. (1994): Režim a jakost povrchové vody v povodí Smědé. Thesis. PřF UK, Praha, $98 \mathrm{p}$.

ŠVIHLA, V. et al. (1992): Výzkumný objekt Ovesná Lhota. Monographz. VÚMOP, Praha, $92 \mathrm{p}$.

VÁLEK, Z. (1953): Výzkum vlivu lesa na odtok v povodí Kychové a Zděchovky. Vodní hospodáŕství, No. 10-11, Praha.

VESECKÝ et al. (1961): Podnebí Československé socialistické republiky. Tabulky. Hydrometeorologický ústav, Praha.

VONDRA, F. (2004): Fyzickogeografická charakteristika a antropogenní ovlivnění povodí horní Blanice. Bakalářská práce, PřF UK, Praha, 68 p.

Shrnutí

\section{ZMĚNY ODTOKOVÉHO REŽIMU V DU゚SLEDKU ANTROPOGENNÍCH ZMĚN V KRAJINĚ}

Nedávno proběhlé povodňové události v Česku vyvolaly četné diskuse o negativním vlivu člověka na řiční systém a následně i na změny ve srážko-odtokových poměrech. Prezentované odborné studie o přímém či nepřímém vlivu člověka na odtokový režim jsou mnohdy protichůdné, což může být způsobeno heterogenitou zvolených povodí, avšak do jisté míry to může souviset i s absencí komplexního pohledu na povodí.

Hlavním cílem prezentované studie bylo objasnění př́íčin prokázaných změn ve vývoji srážko-odtokových poměrů v pramenné oblasti povodí Otavy (viz Kliment, Matoušková 2005). Vzájemně byla porovnávána tři plošně srovnatelná povodí s rozdílným krajinným pokryvem a různým stupněm upravenosti říčního systému : povodí Vydry (profil Modrava), povodí horní Blanice (profil Blanický Mlýn) a povodí Ostružné (profil Kolinec). Změny v odtokovém režimu byly hodnoceny pomocí metody jednoduchých a podvojných součtových čar za období hydrologického pozorování, tj. cca za posledních 50 let. Vedle průměrných odtokových a srážkových charakteristik byly sledovány minimální a 5leté a vyšší průtoky a změny ve vývoji rozložení odtoku během roku. Vývoj odtoku v daných povodích byl dále doplněn o analýzu vývoje teploty vzduchu a sněhových poměrů. Za reprezentativní byly vzaty údaje ze tři výškově různě položených klimatologických stanic ČHMÚ: Klatovy, Kašperské Hory a Churáňov. V návaznosti na analýzy trendů odtokového, srážkového a teplotního režimu byly provedeny analýzy změn ve využití krajiny, upravenosti rríční sítě a plošné- 
ho odvodnění pozemků. Při zpracování bylo využito jak existujících analogových a digitalizovaných databází, tak vlastního terénního průzkumu.

Ze třech modelových povodí se odchylky $\mathrm{v}$ odtoku nejvíce projevily v zemědělsky využívaném povodí Ostružné, méně výrazně v povodí horní Blanice a nebyly naopak zjištěny $\mathrm{v}$ přírodním zalesněném povodí Vydry. Změny se projevily zřetelným nárủstem odtoku v 70. a 80. letech minulého století a postupným úbytkem odtoku v následném období. Analýzou vývoje rozložení odtoku a srážek $\mathrm{v}$ průběhu roku byly zjištěny určité vazby nárůstu odtoku na jedno ze srážkově bohatších období s vyšším podílem odtoku v mimovegetačním období. Teplotně chladné, relativně souvislé období bylo charakteristické výskytem srážkově průměrných až nadprůměrných let bez výrazných výkyvů s nadprůměrnou výškou sněhové pokrývky a nadprůměrným počtem dní se sněhovou pokrývkou. Po r. 1982, hlavně pak v 90. letech, lze pozorovat zejména $\mathrm{v}$ souvislosti $\mathrm{s}$ nárůstem teplot $\mathrm{v}$ letních i zimních měsících $\mathrm{v}$ průměru nižší až nízké hodnoty odtoku, především ve vegetačním období. Vzhledem ke specifičnosti a neopakovatelnosti zjištěného trendu odtoku za více jak 50leté období a jeho neidentifikaci $v$ přírodním zalesněném povodí Vydry můžeme usuzovat, že se na něm mohly spolupodílet některé antropogenně podmíněné zásahy. V tomto smyslu se jedná zejména o rozsáhlá hydromeliorační opatření v zemědělsky využívaných oblastech, provázená úpravami hydrografické sítě a výstavbou povrchových i podpovrchových odvodňovacích systémů. Období nejintenzivnějšího nárůstu odvodněných ploch časově koresponduje se zjištěným trendem nárůstu odtoku. Významný pokles výměry orné půdy kompenzovaný nárưstem zatravněných a zalesněných ploch $\mathrm{v}$ posledním desetiletí mohl naopak přispět spolu se zjištěnými klimatickými trendy ke zvýšení podílu evapotranspirace a tím i k celkovému snížení odtoku. Stanovení váhy a vlivu faktorů ovlivňujících odtok vody z území bude předmětem zahájeného synchronního kontinuálního monitoringu odtoku a srážek na rozdílně využitých dílčích experimentálních plochách s různým stupněm upravenosti říční sítě v lokalitě Zbytiny v povodí horní Blanice.

Obr. 1 - Povodí Otavy - vymezení zájmových území: povodí Vydry, Blanice a Ostružné. Zdroj: ZVM 1:50 000.

Obr. 2 - Podvojné součtové čáry průměrných ročních srážek a průměrných ročních průtoků pro profily: Modrava, Kolinec, Blanický Mlýn. Zdroj: ČHMÜ.

Obr. 3 - Chod průměrných teplot vzduchu v jednotlivých ročních obdobích, 5letý plovoucí průměr. Zdroj: ČHMÚ.

Obr. 4 - Změny krajinného pokryvu v povodí Ostružné. Zdroj: CORINE Land cover.

Obr. 5 - Upravenost říční sítě a odvodnění ploch v povodí Ostružné. Zdroj: ZVHS Prachatice.

Obr. 6 - Plošné odvodnění v povodí Ostružné a Blanice. Zdroj: ZVHS Prachatice.

Obr. 7 - Vývoj klimatu a nárůst plošného odvodnění v povodí Ostružné v období1954-2002. Zdroj: ČHMÚ, ZVHS. $Q$ - průměrný průtok, $H$ - srážky, $T$ - průměrná teplota vzduchu, $S D$ - výška sněhové pokrývky, $S N$ - počet dnů se sněhovou pokrývkou. Černě > horní kvartil, tmavě šedá < horní kvartil, medián >, světle šedá < medián, dolní kvartil >, bílá:< dolní kvartil. Slabá čára: vývoj plošného odvodnění, silná čára: kumulativní vývoj plošného odvodnění.

(Authors are with Charles University in Prague, Faculty of Science, Department of Physical Geography and Geoecology, Albertov 6, 12843 Praha 2, Czechia;

e-mail:kliment@natur.cuni.cz, matouskova@natur.cuni.cz.) 